\title{
Regular Article \\ In vitro Evaluation of Antibacterial Efficacy using Passiflora foetida Activated Carbon
}

\author{
${ }^{*}$ Dheeban Shankar Pa, Basker $\mathbf{S}^{b}$ KarthikKc and Karthik $\mathbf{S}^{\mathrm{d}}$ \\ a Research and Development Centre, Bharathiar University, Coimbatore-46, Tamil Nadu \\ a,d Department of Biotechnology, Nandha Arts and Science College, Erode-52, Tamil Nadu \\ b Department of Botany, Government Arts College, Salem-7, Tamil Nadu \\ c Department of Chemistry, Nandha Arts and Science College, Erode-52, Tamil Nadu \\ * Corresponding author Email: deepanbala@gmail.com
}

Activated carbon (AC) has found its attention in pollution control and wastewater treatment to remove various pollutants. Activated carbon can be prepared by physical and chemical activation methods. The chemical activation methods were advantageous over physical activation due to process accomplishment at lower temperature and greater yield which avoids burn-off char. Activated carbon was usually used as an adsorbent for dye removal from wastewater which could be related to their extended surface area, high adsorption capacity, microporous structure and special surface reactivity. Microbial pollution and contamination have produced various problems in industrial and medical fields. Based on this, the present study was attempted on the preparation of activated carbon from Passiflora foetida and evaluating for its antibacterial efficacy against twelve different microorganisms by agar well diffusion method. The results were found to be very effective with higher zone of inhibition against almost all the microorganisms tested. Moreover, the activity was considerably more against Shigella flexneri (MTCC 1457) and Klebsiella pneumoniae (MTCC 10309).In addition to this, the shake flask test in saline had proved that the colonial growth of E.coli was inhibited with respect to the concentration of activated carbon and time of incubation.

Key words: Activated carbon, Adsorption capacity, Antimicrobial, Passiflora foetida, Agar well diffusion etc.

Activated carbon has been widely used for the removal of various organic and inorganic pollutants in wastewater or gaseous media because of its large surface area and high adsorption capacity (OrtizIbarraet al., 2007; Cook et al., 2001 and Crittenden et al., 1993). In recent years, there is a growing research interest in the production of activated carbon and surface modified activated carbon from renewable and cheaper precursors which are mainly plant materials and agricultural by-products, especially used in applications concerning wastewater treatment. The preparation of activated carbon is attracting the interest of researchers all over the world. The precursors of preparation reported are agricultural byproducts forest wastes and plant materials such as coconut shell (Radhika and Palanivelu, 2006), sugar beet bagasse (Onal et al., 2007), rice straw (Wang et al., 2007), ashoka leaf powder (Joseph et 
al.,2011), tamarind kernel powder (Raffiea Baseri et al., 2012), Casuarina (Supriya et al.,2014).Microbial pollution and contamination that takes place by microorganisms have produced various problems in industry and other vital fields including medicine (Mattsby-Baltzer et al., 1989).The activated carbons were excellent in affinity with microorganisms and adsorb large amount of bacteria(Yamamoto et al., 2000). Activated carbon has proven to remove bacteria like Pseudomonas aeruginosa and Escherichia coli fromfresh and potable water systems (Percival and Walker, 1999; Quinlivan et al., 2005). Modification in the activated carbon particles by coating with a quaternary ammonium compound gives bactericidal properties to the activated carbon particles (Shi et al., 2007).Antimicrobial action of plants viz., Passiflora foetida (Mohanasundari et al.,2007), Artabotrys hexapetalus (Dheeban Shankar et al., 2015), Common weeds (Bhuvaneswari et al.,2011)and Antibacterial Activity of Activated Carbon, Silver, Silver Impregnated Activated Carbon and Silica Sand Nanoparticles (Karnib et al., 2013).Activated carbon from Tribulus terrestris(Karthik and Saraswathy, 2015) and Activated carbon sphere with antibacterial properties (Yamamoto et al., 2002) were reported which made a platform and interest to perform the current research on Passiflora foetida.

The genus Passiflora, comprising about 500 species, is the largest in family Passifloraceae (the Passion flower family) (Hickey and King, 1988; Maout and Decaisne, 1876; Rendle, 1959). The species of this genus are distributed in the warm temperate and tropical regions of the New World. Passiflora foetida L. commonly known as passion fruit is an exotic fast-growing perennial vine occurring in USA and extended to India. It is widely distributed and especially available in temperate regions throughout the year. Traditionally, the fresh or dried whole plants and their preparations are accepted for medicinal use in European countries for the treatment of nervous anxiety. Leaves of the plant utilized as folk medicine for treatment of anti-anxiety, stress and insomnia. Additional, they are also useful for the treatment of hysteria, skin inflammation, cough and fever. The chemical constituents in $P$. foetida include hydrocyanic acid, groups of flavonoids and Harman alkaloids. In India, the leaves are used in wound dressing and also applied to head to treat the headache and giddiness by the trial people (Wagner et al., 1990; Shah et al., 1970). The stems grow 1.5 to $6 \mathrm{~m}$ in height. It appears cylindrical in shape, thin, wiry and woody, covered with sticky yellow hairs on a total surface. They give off an unpleasant odor when crushed. So stems and leaves are not grazed over by the livestock and are suspected to contain poison (Patil et al., 2013)

To the best of knowledge, the preparation and antimicrobial property of activated carbon from Passiflorafoetida by chemical method have not been reported so far in literature. Therefore, the current research was attempted to focus on preparation of activated carbon using Passiflora foetida and evaluation of its antibacterial efficacy.

\section{Materials and Methods Collection of Passiflora foetida}

Passiflora foetida(Fig.1.)was collected from in and around Erode District, Tamil $\mathrm{Nadu}$, India. The plant materials were taxonomically identified and authenticated by the Botanical survey of India [BSI], TNAU, Coimbatore. The voucher specimen was deposited there for future reference and registered with no: BSI/SRC/5/23/201415/Tech-1085.The plants were surface cleaned with tap water followed by sterile distilled water.The stem (Fig.2a) of the plant alone was taken and cut into small pieces and dried under shadow for about 15-20 days. The dried material was ground in a domestic blender to a fine powder. The powdered 
biomass was stored in an airtight plastic container and used for the preparation of Activated carbon.

\section{Acid modified Passiflora foetida Activated carbon}

Acid modified Passiflora foetida powder adsorbent was prepared according to the method of Karthik and Saraswathy, (2015). The raw powder was mixed with excess of Sulphuric acid solution following charring of the materials occurred immediately with evolution of fumes and heats in both the cases. When the reaction subsided, the whole reaction mixture was placed in an oven maintained at $120-140^{\circ} \mathrm{C}$ for a period of 24 hours. The final mixture was filtered and repeatedly washed with distilled water to remove excess presence of free acid residues. The washed material was dried and finally activated at $180{ }^{\circ} \mathrm{C}$ in hot air oven.

\section{Antibacterial efficacy by agar well diffusion method \\ Microorganisms used}

The following microorganisms were purchased from Microbial Type culture collection, IMTECH, Chandigarh and the prepared 18 hours testinoculums were used for checking antibacterial efficacy.

\section{Gram positive bacteria}

Bacillus cereus(MTCC 430), Staphylococcus aureus (MTCC 3160), Corynebacterium sp (MTCC 3603),Enterococcus sp(MTCC 9728), and Micrococcus luteus(MTCC 106)

\section{Gram negative bacteria}

Escherichia coli (MTCC 1698), Klebsiella pneumoniae (MTCC 10309),Proteus vulgaris(MTCC 744),Alcaligenes faecalis(MTCC 3104) Pseudomonas aeruginosa (MTCC 424), Salmonella typhimurium (MTCC 3231)and Shigella flexneri(MTCC 1457)

Activated carbon obtained from the stem of Passiflora foetida were tested for its potential antibacterial activity against the above mentioned microorganisms. Agar well diffusion assay method was followed, which involves the swabbing of microbial cultures in pre-sterilized Mueller Hinton agar plates and four wells were cut in the same using sterile cork borer. $100 \mu \mathrm{l}$ of the solutions in the following order viz., DMSO as control, Stem powder, Carbon and Activated carbon suspended in DMSO was loaded into the respective well. Then the sample loaded agar plates were incubated at $37^{\circ} \mathrm{C}$ for 24 hours. The activity was evidenced by the formation of zone of inhibition surrounding the well and the antibacterial activity was expressed as the inhibition zones $(\mathrm{mm})$ produced by the activated carbon when compared to the controls.

\section{Shake flask test in saline}

The shake flask test was carried out according to the method described by Karnib et al.,(2013) with slight modifications. In this test, $50 \mathrm{ml}$ of sterile saline $(0.9 \% \mathrm{NaCl})$ was inoculated with $1 \mathrm{ml}$ bacterial suspension (E.coli) following the addition of different concentration of activated carbon as $50 \mathrm{mg}$, $100 \mathrm{mg}$, 250mg and 500mg with suitable control in which the activated carbon was not added. The contents were stirred on a rotary shaker at ambient temperature. The samples were drawn periodically $(0,1,4$ and 24 hours) from the flask and observed for surviving E.coli on nutrient agar.

\section{Results and Discussion}

The activated acid modified carbon obtained from the stem of Passiflora foetida shown in (Fig.2b.) when subjected to screen the antibacterial property, it exhibited good and tremendous antibacterial potency with clear zone of inhibition on almost all the twelve microorganisms evaluated. On testing with the stem powder, carbon and activated carbon suspension, Stem powder inhibited with minimum effect against Bacillus cereus, Escherichia coli and Shigella flexneri. To its 
part, Carbon also had shown the moderate action over few microorganisms tested but activated carbon had proved its maximum efficiency in inhibition against Shigella flexneri and Klebsiella pneumoniae following more or less, the equivalent action over the other pathogens that were screened. The zone of inhibition in diameter is mentioned in the table 1 and the images were depicted in figure 3. Activated carbon had proved that it contains the antibacterial properties and is clearly indicating their use and need in water purification system. In addition, the shake flask test in saline had shown for the reduction in the number of colonies with respect to the concentration of activated carbon and time of incubation. The activated carbon at a concentration of $250 \mathrm{mg}$ and $500 \mathrm{mg}$ revealed the considerable reduction in the number of surviving E.coli colonies after 24 hours of incubation when compared to $50 \mathrm{mg}$ and $100 \mathrm{mg}$. The reduction in colonies were further confirmed with the uncountable colonial growth in the control plate. From this it was confirmed that the activated carbon had proved its efficiency of microbial growth inhibition. The colonial growth obtained in the control plate, $250 \mathrm{mg}$ and $500 \mathrm{mg}$ of activated carbon after 24hours of incubation were clearly displayed in the fig. 4.The carbon used in the current study was activated at $180^{\circ} \mathrm{C}$ suggesting that it had best action when compared to the similar study in which the carbon from Tribulus terrestris used was activated at $800{ }^{\circ} \mathrm{C}$ (Karthik and Saraswathy, 2015).

Most of the literature were reported on the removal of dye using activated carbon but only a very few reports on the antibacterial properties. The results in the present study were found to support the work of Percival and Walker (1999); Quinlivan et al., (2005).Thus the activated carbon can be used not only as an adsorbent for dye removal but also as the best antimicrobial agent and adsorbent of bacteria as reported by Yamamoto et al. (2000). Still the preparation of activated carbon from various agricultural sources and the deep research on the mode of action of activated carbon are essential to have an effective way of controlling microorganisms in the filtration systems.
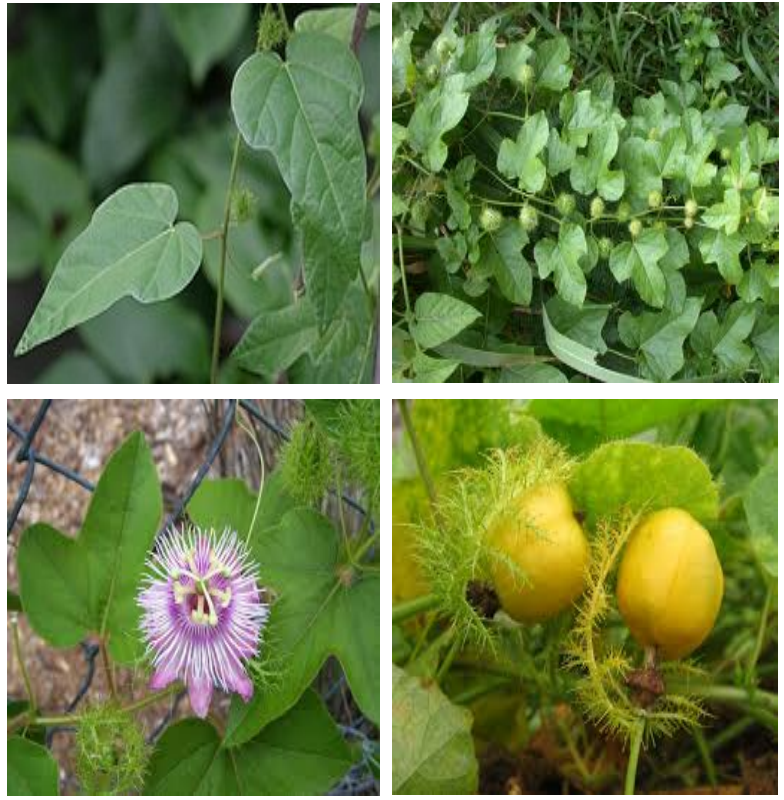

Fig. 1. Images of Passiflorafoetida

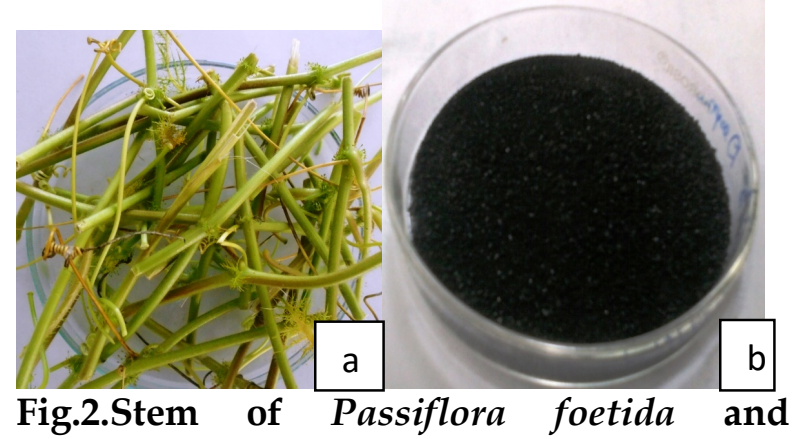

Activated carbon 


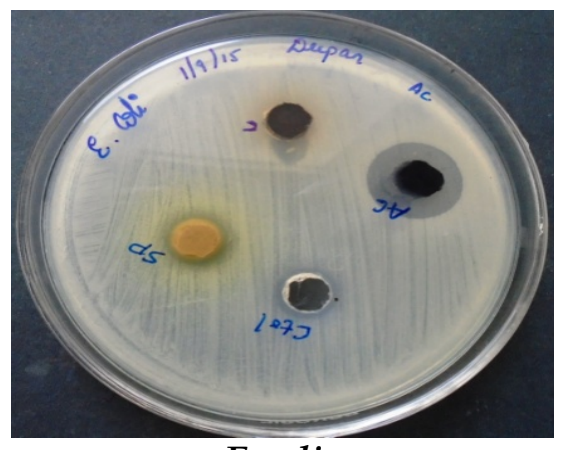

E.coli

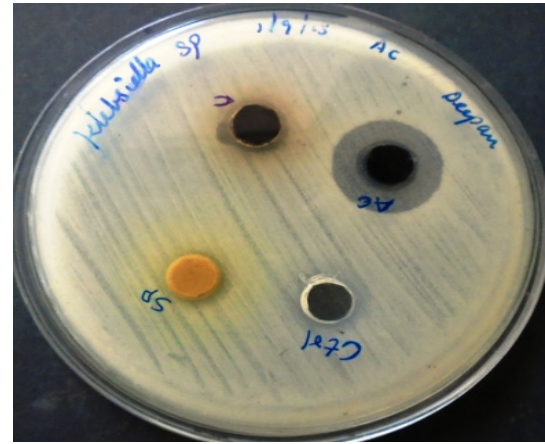

Klebsiella pneumoniae

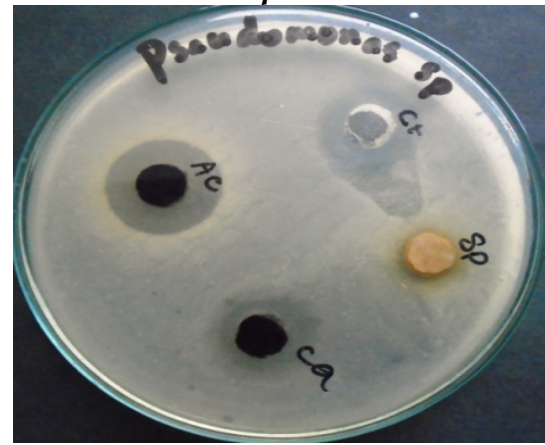

Pseudomonas aeruginosa

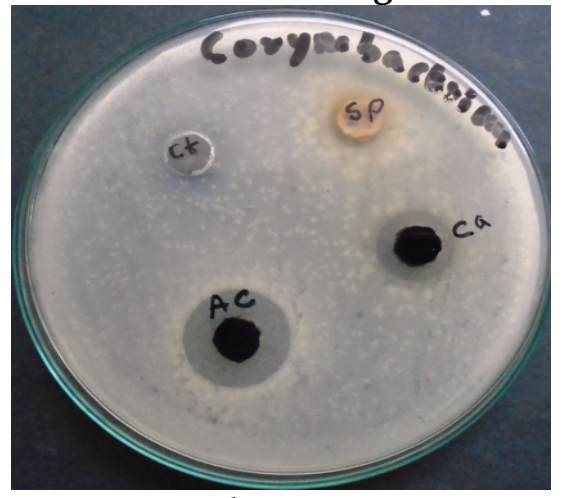

Corynebacterium $s p$

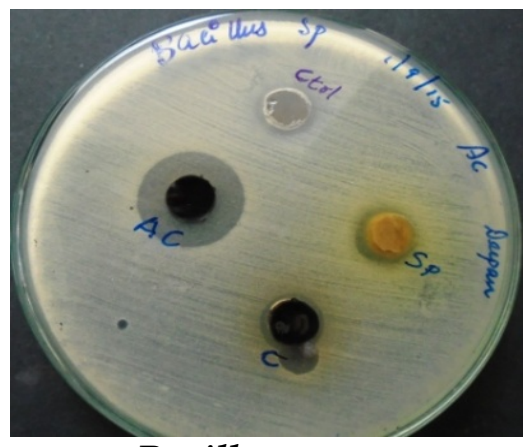

Bacillus cereus

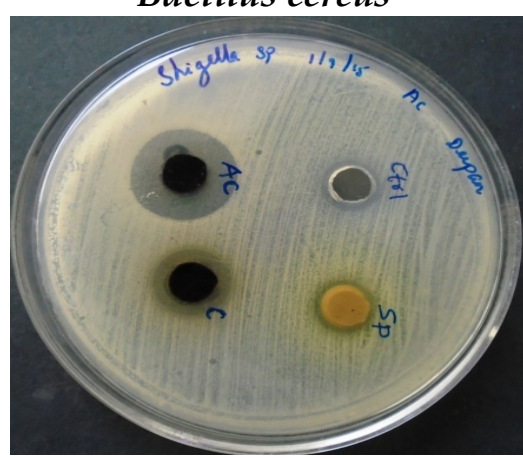

Shigellaflexneri

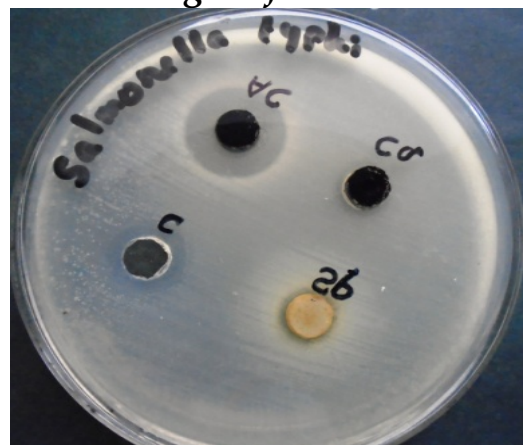

Salmonella typhimurium

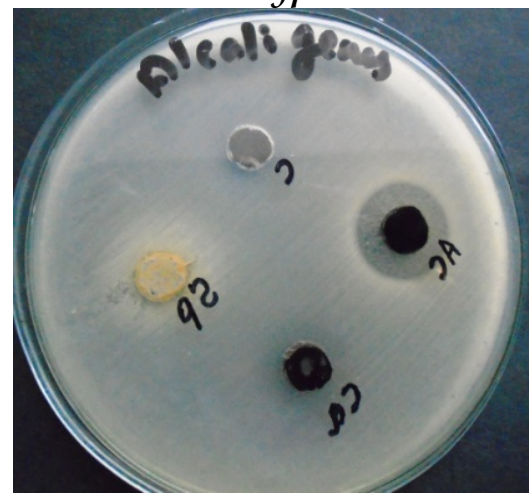

Alcaligenes faecalis

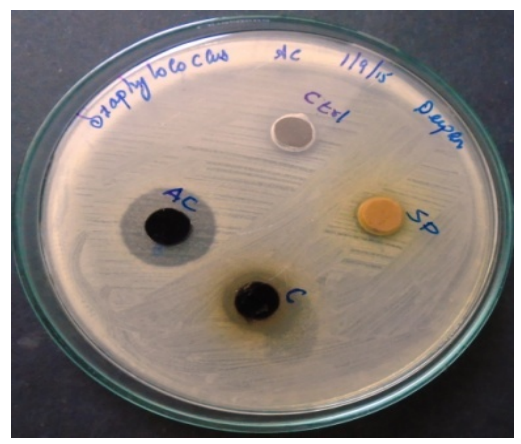

Staphylococcus aureus

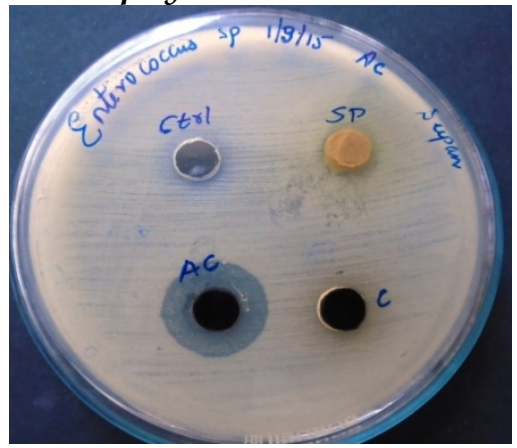

Enterococcus $s p$

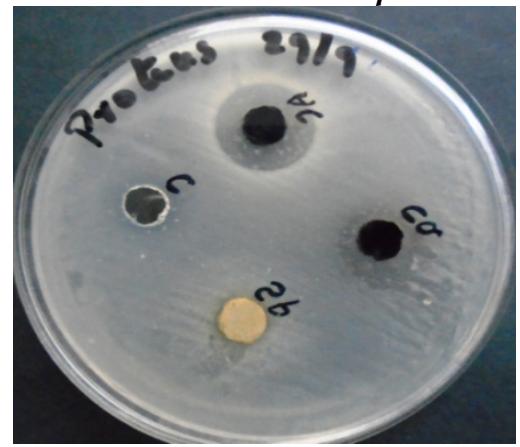

Proteus vulgaris

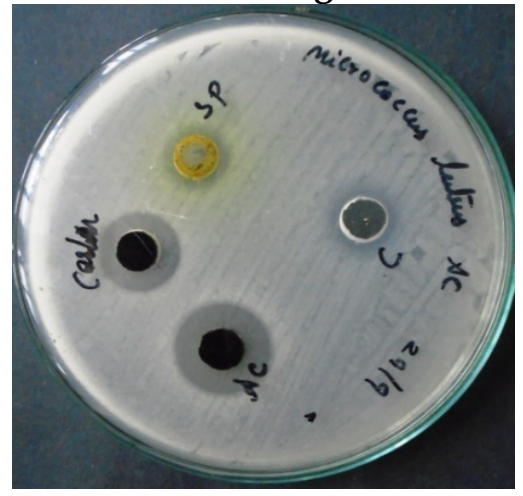

Micrococcus luteus

Fig.3. Antibacterial efficacy of Activated carbon from Passiflora foetida 
Table 1. Antibacterial Efficacy using Passiflora foetida activated carbon

\begin{tabular}{|c|c|c|c|c|c|c|c|}
\hline \multirow[b]{2}{*}{ S.No. } & \multirow{2}{*}{$\begin{array}{l}\text { Category } \\
\text { of Bacteria }\end{array}$} & \multirow[b]{2}{*}{ Test Microorganisms } & \multirow{2}{*}{$\begin{array}{l}\text { Volume } \\
\qquad(\mu \mathrm{l})\end{array}$} & \multicolumn{4}{|c|}{ Zone of inhibition in Diameter (mm) } \\
\hline & & & & Control & $\begin{array}{c}\text { Stem } \\
\text { powder }\end{array}$ & Carbon & $\begin{array}{c}\text { Activated } \\
\text { carbon }\end{array}$ \\
\hline 1 & \multirow{5}{*}{$\begin{array}{c}\text { Gram } \\
\text { Positive } \\
\text { Bacteria }\end{array}$} & $\begin{array}{l}\text { Bacillus cereus } \\
\text { (MTCC 430) }\end{array}$ & 100 & Nil & 10 & 11 & 19 \\
\hline 2 & & $\begin{array}{l}\text { Staphylococcus aureus } \\
\text { (MTCC 3160) }\end{array}$ & 100 & Nil & Nil & 14 & 19 \\
\hline 3 & & $\begin{array}{l}\text { Enterococcus Sp } \\
\text { (MTCC 9728) }\end{array}$ & 100 & Nil & Nil & Nil & 20 \\
\hline 4 & & $\begin{array}{l}\text { Micrococcus luteus } \\
\text { (MTCС 106) }\end{array}$ & 100 & Nil & Nil & 15 & 19 \\
\hline 5 & & $\begin{array}{l}\text { Corynebacterium Sp } \\
\text { (MTCC 3603) }\end{array}$ & 100 & Nil & Nil & 14 & 19 \\
\hline 6 & \multirow{7}{*}{$\begin{array}{c}\text { Gram } \\
\text { Negative } \\
\text { Bacteria }\end{array}$} & $\begin{array}{l}\text { Escherichia coli } \\
\text { (MTCC 1698) }\end{array}$ & 100 & Nil & 12 & Nil & 20 \\
\hline 7 & & $\begin{array}{l}\text { Klebsiella pneumoniae } \\
\text { (MTCC 10309) }\end{array}$ & 100 & Nil & Nil & 12 & 21 \\
\hline 8 & & $\begin{array}{l}\text { Pseudomonas aeruginosa } \\
\text { (MTCC 424) }\end{array}$ & 100 & Nil & Nil & 14 & 20 \\
\hline 9 & & $\begin{array}{l}\text { Shigellaflexneri } \\
\text { (MTCC 1457) }\end{array}$ & 100 & Nil & 11 & 15 & 22 \\
\hline 10 & & $\begin{array}{l}\text { Salmonella typhimurium } \\
\text { (MTCC 3231) }\end{array}$ & 100 & Nil & Nil & 11 & 19 \\
\hline 11 & & $\begin{array}{l}\text { Proteus vulgaris } \\
\text { (MTCC } 744)\end{array}$ & 100 & Nil & Nil & Nil & 19 \\
\hline 12 & & $\begin{array}{l}\text { Alcaligenesfaecalis } \\
\text { (MTCC 3104) }\end{array}$ & 100 & Nil & Nil & Nil & 18 \\
\hline
\end{tabular}

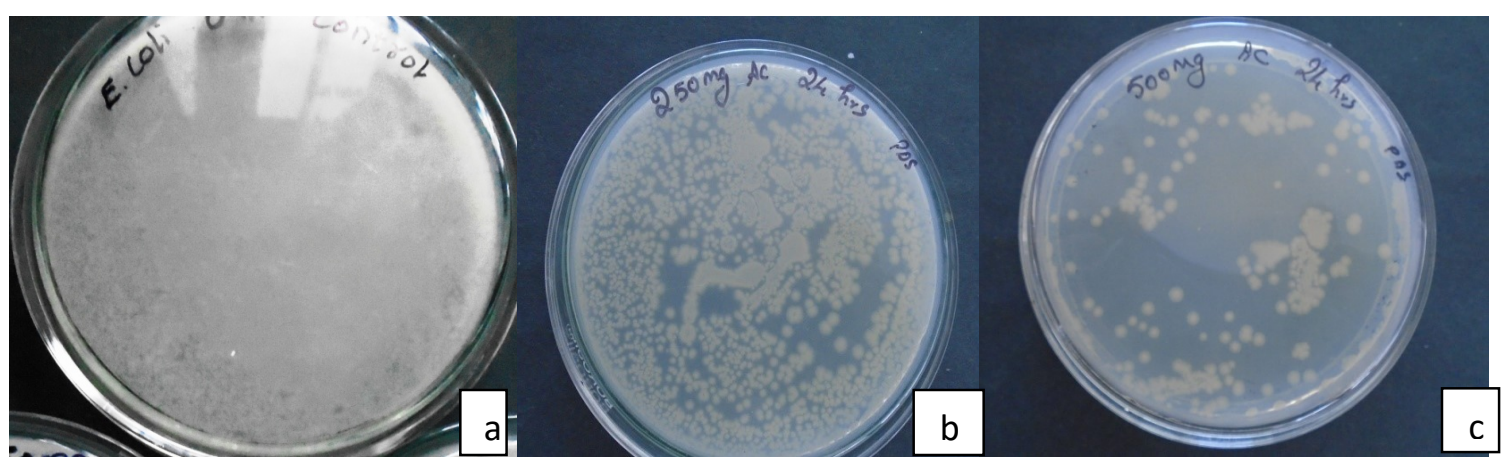

Fig. 4. Image showing colonial growth inhibition of E.coli after 24 hours incubation by shake flask test a.Control, b. Reduction in number of colonies after 24 hours at $250 \mathrm{mg}$ of activated carbon, c. Reduction in number of colonies after 24 hours at $500 \mathrm{mg}$ of activated carbon. 


\section{References}

Bhuvaneswari S., Aravind R., KaviyarasanV., Kalaivanan K. and Sekarbabuhariram. (2011). A Comparative study on antibacterial activity of common weeds. Int. J. Pharma Bio Sci. 2(1): 678-683.

Cook D., Newcombe G. and Sztajnbok P. (2001). The application of powdered activated carbon for MIB and geosmin removal: predicting PAC doses in four waters. Water Res. 35(5): 9.

Crittenden J., Vaitheeswaran K., Hand D., Howe E., and Aieta E. (1993). Removal of dissolved organic carbon using granular activated carbon. Water Res. 27(4): 7.

Dheeban Shankar P., Ananthi P., and Basker S. (2015). Phytochemical Screening and Antibacterial efficacy of Artabotrys hexapetalus. Res. Plant Bio. 5(3): 10-13.

Hickey M, King C, (1988) 100 Families of Flowering Plants. Cambridge University Press, Cambridge. pp. 130-133.

Joseph $\mathrm{T}$ Nawabnne and Philomena K zlgbokwe. (2011). Copper (II) Uptake by Adsorption Using Palmyra Palm Nut. Adv. Appl. Sci. Res. 2(6): 166-175.

Karnib M., Holail H., Olama Z., Kabbani A., and Hines M. (2013).The Antibacterial Activity of Activated Carbon, Silver, Silver Impregnated Activated Carbon and Silica Sand Nanoparticles against Pathogenic E. coli BL21. Int. J. Curr. Microbiol. App. Sci. 2(4): 20-30.

Karthik K and Saraswathy C.P. (2015). Antimicrobial Activity of Chemically modified Activated carbon of Tribulus terrestris. Res. Biotech. 6(3): 42-46.

Karthik K. and Saraswathy C.P. (2015). Removal of Methylene blue by adsorption using Tribulus terrestris activated carbon. Int. J. Advan. Chemical Sci. App. 3(1): 1-5.

Maout LE, Decaisne J., (1876) .A General System of Botany. Longmans, Green and Company, London. pp. 446-449

Mattsby-Baltzer I., Sandin M., Ahlstrom B, Allenmark S., Edebo, Falsen E., Pederson
K., Rodin N,Thompson R.A, and Edebo L.(1989). Microbial growth and accumulation in industrial metal-working fluids. Appl. Environ. Microbiol. 55(10): 2681-2688.

Mohanasundari C., Natarajan D., Srinivasan K., Umamaheswari S. and Ramachandran A. (2007) Antibacterial properties of Passiflora foetidaL. - acommon exotic medicinal plant. Afr. J. Biotech. 6 (23): 2650-2653.

Onal Y., Akmil-Basar C., Sarici-Ozdemir C., and Erdogan S. (2007) .Textural development of sugar beet bagasse activated with $\mathrm{ZnCl}_{2}$. J. Hazard. Mater. 142 (1-2): 138-143.

Ortiz-Ibarra H., Casillas N., Soto V., BarcenaSoto M., Torres-Vitela R., Dela Cruz W. and Gomez-Salazar S. (2007). Surface characterization of electrodeposited silver on activated carbon for bactericidal purposes. J. Colloid. Inter. Sci. 314: 562571.

Patil A.S., Paikrao H.M. and Patil S.R. (2013).Passiflora foetida Linn: A complete morphological and phytopharmacological review. Int. J. Pharm. Bio. Sci. 4(1): 285 296.

Percival S L, and Walker JT, (1999) Potable water and biofilms: a review of the public health implications. Biofoul. 14: 99-115.

Quinlivan A., Li L., and Knappe D. (2005).Predicting Adsorption Isotherms for Aqueous Organic Micropollutants from Activated Carbon and Pollutant Properties. Water Res. 39:1663-1673.

Radhika M. and Palanivelu K. (2006). Adsorptive removal of chlorophenols from aqueous solution by low cost adsorbent-Kinetics and isotherm analysis. J. Hazard. Mater. 138 (B): 116-124.

RaffieaBaseri J., Palanisamy P.N., and Sivakumar P. (2012). Preparation and characterization of activated carbon from Thevetia peruviana for the removal of dyes 
from textile waste water. Adv. Appl. Sci. Res. 3:377-383.

Rendle A.B. (1959). Classification of Flowering Plants. Cambridge University Press, Cambridge. pp. 211-213.

Shah J.J. and Dave YS. (1970). Tendrils of Passiflorafoetida: Histogenesis and Morphology. Amer J Bot. 57(7): 786-793.

Supriya S., Palanisamy P.N., and Shanthi P. (2014). Preparation and Characterization of Activated Carbon from Casuarina for the Removal of Dyes from Textile Waste water. Int. J. Chem Res. 6(7): 3635-3641.

Wagner W.L., Herbst D.R., Sohmer S.H. (1990) Ed. Manual of the flowering plants of Hawaii. 2 vols. Univ. Hawaii Press \& Bishop Museum Press, Honolulu. 1: 853.

Wang S. L., Tzou Y.M., Lu Y. H., and Sheng G. (2007). Removal of 3-chlorophenol from water using rice-straw-based carbon. J. Hazard. Mater. 147:313-318.

Yamamoto O., Nakakoshi O. K., Sawai J., Sasamoto T. (2000). Adsorption of Bacteria In Spherical Carbon Prepared From IonExchange Resin.Tanso.191:42-44.

Yamamoto Osamu, Jun Sawai and Tadashi Samamoto. (2002). Activated carbon sphere with antibacterial characteristics. Mat trans. 43(5): 1069-1073. 